\title{
Vitamin D and Rehabilitation after Stroke: Status of Art
}

\author{
Mariacristina Siotto, Massimo Santoro* (D) and Irene Aprile \\ IRCCS, Fondazione Don Carlo Gnocchi, 20121 Milan, Italy; msiotto@dongnocchi.it (M.S.); \\ iaprile@dongnocchi.it (I.A.) \\ * Correspondence: masantoro@dongnocchi.it; Tel.: +39-063-308-6318
}

Received: 30 January 2020; Accepted: 10 March 2020; Published: 13 March 2020

\begin{abstract}
Stroke is the first cause of disability in the population and post-stroke patients admitted to rehabilitation units often present a malnutrition status which can influence nutritional indices and then vitamin levels. Vitamin D deficiency seems implicated beyond stroke severity and stroke risk, and also affects post-stroke recovery. Some studies on vitamin D levels and outcome in stroke patients are available but very few data on vitamin D levels and outcome after rehabilitation treatment are reported. This literature review shows the possible relationship between vitamin D deficiency and recovery in post-stroke patients undergoing rehabilitation treatment. Moreover, because several studies have reported that single nucleotide polymorphisms and promoter methylation in genes are involved in vitamin D metabolism and might affect circulating vitamin D levels, these aspects are evaluated in the current paper. From the studies evaluated in this review, it emerges that vitamin D deficiency could not only have an important role in the recovery of patients undergoing rehabilitation after a stroke, but that genetic and epigenetic factors related to vitamin D levels could have a crucial role on the rehabilitation outcome of patients after stroke. Therefore, further studies are necessary on stroke patients undergoing rehabilitation treatment, including: (a) the measurement of the $25(\mathrm{OH})$ vitamin D serum concentrations at admission and post rehabilitation treatment; (b) the identification of the presence/absence of CYP2R1, CYP27B1, CYP24A1 and VDR polymorphisms, and (c) analysis of the methylation levels of these genes pre- and post-rehabilitation treatment.
\end{abstract}

Keywords: vitamin D; stroke; rehabilitation

\section{Introduction}

Stroke remains the first cause of disability in the population [1] and post-stroke patients admitted to rehabilitation units often present a malnutrition status which can influence nutritional indices and then vitamin levels [2].

The vitamin D deficiency is becoming a common worldwide concern. The population considered at a higher risk of vitamin D deficiency are those which have decreased sun exposure [3], but recently it has been calculated that about one billion people in the world are expected to suffer vitamin $\mathrm{D}$ insufficiency or deficiency in different regions and climates, in all age and sex groups $[4,5]$. For this reason, vitamin D deficiency is an important public health problem.

Recently, air pollution, environmental chemicals and smoking have been studied as potential triggers of vitamin D deficiency, disrupting its biochemical pathways and causing detriments of this vitamin [4].

Moreover, vitamin D deficiency has been related to numerous diseases: from musculoskeletal ones [6,7], to chronic illnesses, many cancers, autoimmune diseases, hypertension, cardiovascular diseases, and neurological disorders [8-10]. 
In a recent meta-analysis, a relationship between vitamin D deficiency and stroke severity at onset, risk of stroke, and functional outcome at the follow-up was reported [11]. Few studies evaluated patients undergoing rehabilitation treatment, or vitamin D levels before and after rehabilitation treatment [12-15]. Therefore, we believe that the relationship between vitamin D levels and rehabilitation outcome is topic that needs to be explored.

This literature review, shows: (a) an overview of the metabolism and the genetic/epigenetic aspects of vitamin D, (b) the relationship between vitamin D deficiency and stroke as risk, severity, and outcome, and (c) the influence of vitamin D levels and recovery in post-stroke patients undergoing rehabilitation treatment. Finally, the crucial importance of genetic and epigenetic aspects and vitamin D levels for a better rehabilitation outcome in stroke patients is underlined.

\section{Vitamin D Metabolism}

Vitamin D is a hormone involved in calcium metabolism and bone homeostasis and has a significant function in immune modulation, cell growth regulation, cell proliferation and differentiation $[13,16]$.

Vitamin D (named also calciferol) is provided predominantly through dermis exposure to sunlight and in the smallest portions through intake from diet (food and vitamin supplements).

In the skin, 7-dehydrocholesterol (provitamin D3) is converted into pre-cholecalciferol (previtamin D3) by UV light and then modified into cholecalciferol (vitamin D3). The dietary source of vitamin $\mathrm{D}$ is in the form of ergocalciferol (vitamin D2). Cholecalciferol and ergocalciferol are prohormones transported into the blood by vitamin-D-binding protein (VDBP) but to become active they must be hydroxylated. Once transported in the liver, vitamin D2 and D3 are hydroxylated by the cytochrome P450 mixed-function oxidases, encoded by CYP2R1, and located at endoplasmic reticulum, generating the 25 hydroxy vitamin $\mathrm{D}[25(\mathrm{OH}) \mathrm{D}]$, or calcidiol (in this review we will not differentiate between 25(OH)D2 or 25(OH)D3) [5] (Figure 1).

In the renal tubules of the kidney, 25(OH)D is further hydroxylated by $1 \alpha$-hydroxylase encoding by CYP27B1 and generating 1,25 dihydroxy vitamin $\mathrm{D}\left(1,25(\mathrm{OH})_{2} \mathrm{D}\right.$ or calcitriol) $[17,18]$.

The $1,25(\mathrm{OH})_{2} \mathrm{D}$ (calcitriol), the biologically active molecule, has chemical similarities with typical steroid hormones like estrogen, testosterone and cortisol. $1,25(\mathrm{OH})_{2} \mathrm{D}$ production is downregulated by high levels of calcium and phosphate, while it is upregulated by high levels of the parathyroid hormone (PTH), secreted by the parathyroid glands [5].

The CYP24A1 gene codes for a 24-hydroxylase enzyme which is able to inactivate both $25(\mathrm{OH}) \mathrm{D}$ and $1,25(\mathrm{OH}) \mathrm{D}$ via hydroxylation [18]. Once secreted by the kidney, $1,25(\mathrm{OH})_{2} \mathrm{D}$ is bound by VDBP and it reaches the target organs where the Vitamin D receptor (VDR) mediates its absorption.

VDR, encoded by the VDR gene, is a crucial receptor of the vitamin D endocrine and autocrine systems (Figure 1).

The expression of VDR is ubiquitous. In particular, this receptor is highly expressed in several tissue and cell types such as the small intestine, colon, kidney, bone, skin, the vascular system, endocrine organs, immune system, brain and muscle, with a probable involvement of VDR in the pathophysiology of various diseases, such as several autoimmune disorders, various malignancies, and cardiovascular risk factors [19]. Recent studies suggested an important role of VDR in the molecular physiology of ischemic stroke [20].

Moreover, this VDR is also expressed in the central nervous system, especially in the hippocampus, allowing a high absorption of Vitamin D in this brain district; this evidence argues in favor of a neuroprotective effect exerted by Vitamin D [21]. 


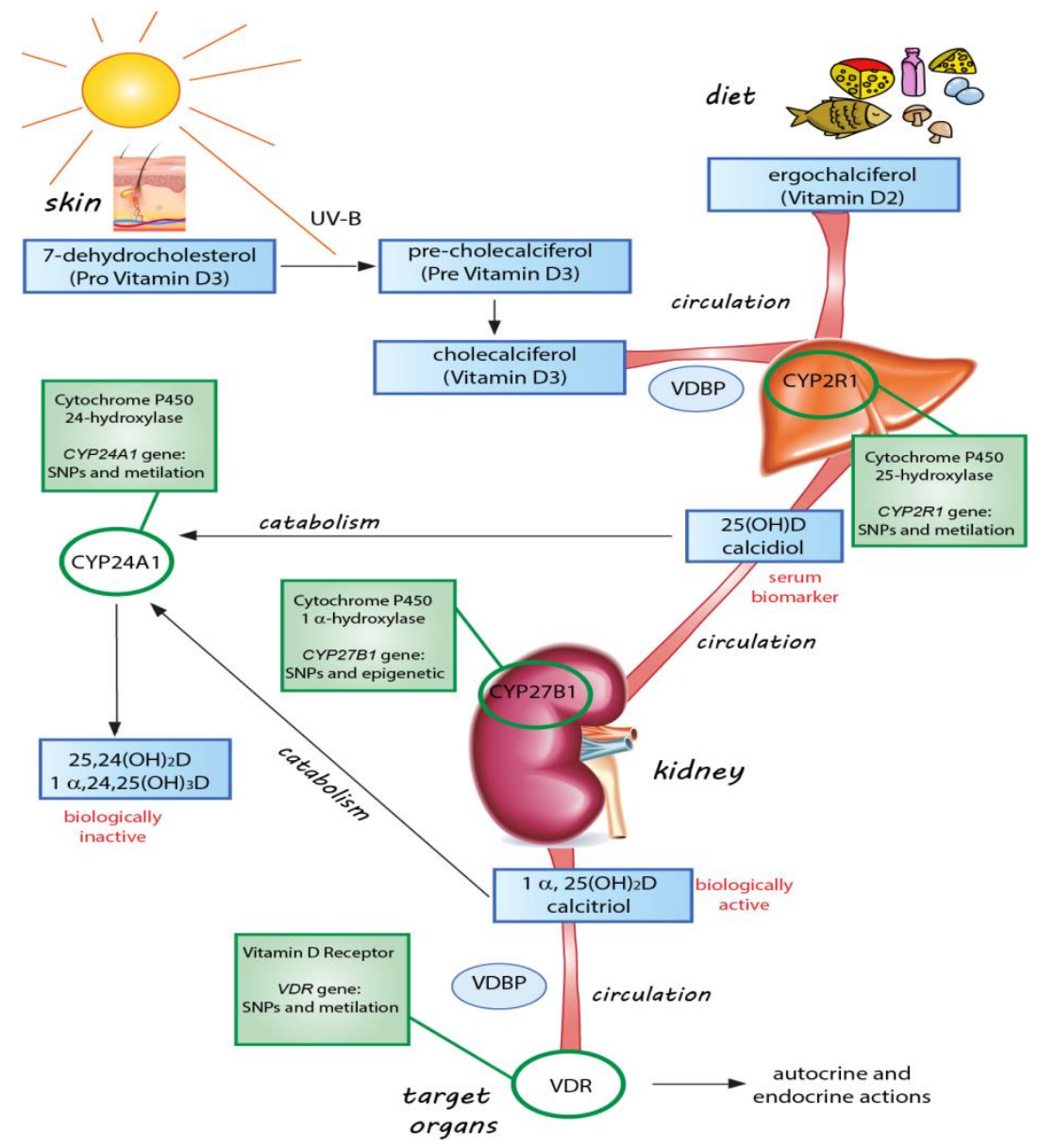

Figure 1. Absorption and metabolism of Vitamin D in human body. Skin or diet: 7-dehydrocholesterol (provitamin D3) is converted into pre-cholecalciferol (previtamin D3) by UV light and then modified into cholecalciferol (vitamin D3). The dietary source of vitamin D is ergocalciferol (vitamin D2). Circulation: Cholecalciferol and ergocalciferol are prohormones transported into the blood by vitamin-D-binding protein (VDBP), but to become active they must be hydroxylated. Liver: Vitamin D2 and D3 are hydroxylated by the cytochrome P450 mixed-function oxidases encoded by CYP2R1 (see green box), generating the 25 hydroxy vitamin D [25(OH)D], or calcidiol. Kidney: 25(OH)D is further hydroxylated by $1 \alpha$-hydroxylase encoding by CYP27B1 (see green box) and generating 1,25 dihydroxy vitamin $\mathrm{D}\left(1,25(\mathrm{OH})_{2} \mathrm{D}\right.$ or calcitriol), which is the biologically active molecule. Catabolic pathway: CYP24A1 gene coding for a 24-hydroxylase enzyme (see green box), which can inactivate both $25(\mathrm{OH}) \mathrm{D}$ and $1,25(\mathrm{OH}) \mathrm{D}$ via hydroxylation. Target organs: $1,25(\mathrm{OH})_{2} \mathrm{D}$ is bound by VDBP and it reaches the target organs where the Vitamin D receptor (VDR) mediates its absorption. VDR, encoded by the VDR gene (see green box), is crucial in the vitamin D endocrine and autocrine systems.

\section{Biochemical Measurements and Dietary Intake}

Plasma or serum concentration of $25(\mathrm{OH}) \mathrm{D}$ is the universally accepted biomarker of vitamin $\mathrm{D}$ status. With respect to the other metabolites, $25(\mathrm{OH}) \mathrm{D}$ properly reflects the nutritional vitamin $\mathrm{D}$ status, having the longest half-life between 2 and 3 weeks; cholecalciferol (Vitamin D3) has a half-live of $24 \mathrm{~h}$, while $1,25(\mathrm{OH})_{2} \mathrm{D}$ has a half-life of only $4 \mathrm{~h}$.

The higher percentage of $25(\mathrm{OH}) \mathrm{D}$ and $1,25(\mathrm{OH})_{2} \mathrm{D}$ in circulation is bound to VDBP $(80-90 \%)$ and albumin $(10-20 \%)$; however, a small portion is free $(0.02-0.05 \%$ of $25(\mathrm{OH}) \mathrm{D}$ and $0.2-0.6 \%$ of $\left.1,25(\mathrm{OH})_{2} \mathrm{D}\right)$.

There is not a consensus on the optimal $25(\mathrm{OH}) \mathrm{D}$ values and two major official reports were published from the Institute of Medicine (IOM) [22] and Endocrine Society [23]. 
The concentration of $25(\mathrm{OH}) \mathrm{D}$ more than $30 \mathrm{ng} / \mathrm{mL}$ (to obtain values in $\mathrm{nmol} / \mathrm{L}$, multiply by values of 2.496) is considered adequate according to the guidelines of Endocrine Society, while for IOM the cut-off is set to $20 \mathrm{ng} / \mathrm{mL}$ [24].

Different methods are employed to test serum 25(OH)D, such as the LC-MSMS (liquid chromatography tandem mass spectrometry), the golden standard, a unique technique able to distinguish between 25(OH)D2 and 25(OH)D3. Chemiluminescence and radioimmunoassay are largely employed together with the Elisa kit.

The dietary reference intake expressed in International Units is from 400 to 1000 IU/day [23]. Ergocalciferol (Vitamin D2) assumed by diet is structurally different from cholecalciferol (Vitamin D3), with a lower affinity for VDBP; this is the reason that supplementation does not result in high serum concentrations of vitamin $\mathrm{D}$ in circulation [24].

\section{Genetic and Epigenetic of Vitamin D Pathway}

\subsection{Gene Polymorphisms}

Single nucleotide polymorphisms (SNPs) in CYP2R1, CYP27B1, CYP24A1 and VDR can affect the vitamin $\mathrm{D}$ concentration in the organism, and many studies have tried to understand how genetic variations in these genes can regulate the vitamin D metabolizing enzymes (Table 1). 
Table 1. Schematic representation of main topics treated in the review with relative references.

\begin{tabular}{|c|c|c|c|c|c|c|c|}
\hline \multirow{4}{*}{$\begin{array}{l}\text { Studies on } \\
\text { Vitamin D } \\
\text { Metabolism }\end{array}$} & \multicolumn{6}{|c|}{ Topic } & \multirow{2}{*}{$\begin{array}{l}\text { References } \\
{[5,13,16-19,21]}\end{array}$} \\
\hline & \multicolumn{6}{|c|}{ General Metabolism } & \\
\hline & \multicolumn{6}{|c|}{ Biochemical Measurements } & [23] \\
\hline & \multicolumn{6}{|c|}{ Dietary Intake } & [23] \\
\hline \multirow{11}{*}{$\begin{array}{l}\text { Studies on } \\
\text { gene related } \\
\text { to vitamin D } \\
\text { pathway: } \\
\text { SNPs and } \\
\text { methylation }\end{array}$} & Gene & SNP & Main topic & References & Promoter Methylation & Main topic & References \\
\hline & \multirow{4}{*}{ CYP2R1 } & rs10741657 & $\begin{array}{l}\text { Risk of vitamin D deficiency. Variable } \\
\text { levels of serum } 25(\mathrm{OH}) \mathrm{D} \text { in elderly } \\
\text { women }\end{array}$ & [25-29] & \multirow{4}{*}{$77 \mathrm{CpG}$ sites } & \multirow{4}{*}{$\begin{array}{l}\text { Hypermethylation in individuals with } \\
\text { severe vitamin D deficiency. } \\
\text { Vitamin D supplementation reduces the } \\
\text { hypermethylation. }\end{array}$} & \multirow{4}{*}[30-32]{} \\
\hline & & rs12794714 & $\begin{array}{l}\text { Variable levels of serum } 25(\mathrm{OH}) \mathrm{D} \text { in } \\
\text { elderly women }\end{array}$ & [27] & & & \\
\hline & & rs1562902 & $\begin{array}{l}\text { Variable levels of serum } 25(\mathrm{OH}) \mathrm{D} \text { in } \\
\text { elderly women }\end{array}$ & [27] & & & \\
\hline & & rs10766197 & $\begin{array}{l}\text { High levels of serum } 25(\mathrm{OH}) \mathrm{D} . \\
\text { Association with multiple sclerosis, } \\
\text { coronary artery disease and risk of } \\
\text { ischemic stroke }\end{array}$ & {$[26-28,33,34]$} & & & \\
\hline & \multirow{3}{*}{ CYP27B1 } & rs10877012 & Risk of cardiovascular disease & [35-38] & \multirow{3}{*}{$91 \mathrm{CpG}$ sites } & \multirow{3}{*}{$\begin{array}{l}\text { Hypomethylation associated with the BMI } \\
\text { in obese children. } \\
\text { Discrepancy in the association between } \\
\text { methylation and plasma } 25(\mathrm{OH}) \mathrm{D} \text { levels, } \\
\text { probably related to the analyzed tissue. }\end{array}$} & \multirow{3}{*}[30,32,39-43]{} \\
\hline & & rs4646536 & $\begin{array}{l}\text { Risk of heart failure in } \\
\text { hypertensive individuals }\end{array}$ & {$[36,44]$} & & & \\
\hline & & rs703842 & Association with multiple sclerosis & {$[45,46]$} & & & \\
\hline & \multirow[b]{2}{*}{ CYP24A1 } & rs927650 & Risk of ischemic stroke & {$[33,47]$} & \multirow[b]{2}{*}{$136 \mathrm{CpG}$ sites } & \multirow{2}{*}{$\begin{array}{l}\text { Methylation is highly variable and appears } \\
\text { to be tissue- and plasma } 25(\mathrm{OH}) \mathrm{D} \\
\text { level-dependent. }\end{array}$} & \multirow[b]{2}{*}[31,32,41,48]{} \\
\hline & & rs2762939 & $\begin{array}{l}\text { Association with coronary } \\
\text { artery calcification }\end{array}$ & [47] & & & \\
\hline & $V D R$ & $\begin{array}{l}\text { rs2228570 } \\
\text { rs7975232 } \\
\text { rs1544410 } \\
\text { rs731236 }\end{array}$ & $\begin{array}{l}\text { Association with cancer, diabetes and } \\
\text { cardiovascular diseases. } \\
\text { Risk of ischemic stroke }\end{array}$ & {$[20,49-53]$} & 71CpG sites & $\begin{array}{l}\text { Variability of methylation levels in } \\
\text { different types of cancer. } \\
\text { Hypermethylation in response to high } \\
\text { plasma levels of } 25(\mathrm{OH}) \mathrm{D} \text {. }\end{array}$ & {$[32,54-56]$} \\
\hline \multirow{5}{*}{$\begin{array}{l}\text { Clinical } \\
\text { studies }\end{array}$} & \multicolumn{6}{|c|}{ Topic } & References \\
\hline & \multicolumn{6}{|c|}{ Vitamin D and risk of stroke } & {$[16,57-66]$} \\
\hline & \multicolumn{6}{|c|}{ Vitamin D and outcome of stroke } & {$[3,11-15,67-71]$} \\
\hline & \multicolumn{6}{|c|}{ Supplementation of Vitamin D and post-stroke recovery } & {$[67,72,73]$} \\
\hline & \multicolumn{6}{|c|}{ Vitamin $\mathrm{D}$ and rehabilitation after stroke } & {$[3,12-15,74]$} \\
\hline
\end{tabular}




\subsubsection{CYP2R1}

Three independent studies reported that individuals with a GG or GA allele for the CYP2R1 rs10741657 polymorphism showed lower levels of $25(\mathrm{OH}) \mathrm{D}$ when compared to AA genotyped individuals $[25,26,75]$.

These dates were confirmed by a meta-analysis (total of 52,417 participants) that showed the association between risk of vitamin D deficiency and allele G of rs10741657 [29].

Moreover, CYP2R1 rs10741657 together with rs12794714, rs1562902, and rs10766197 genetic polymorphisms are responsible for the variability in levels of 25(OH)D in elderly women with vitamin D insufficiency, and these genotypes do not allow the response to vitamin D3 supplementation [27]. Another study conducted on the Danish healthy population showed that higher serum 25(OH)D concentrations are detected in non-carriers of risk alleles of CYP2R1 rs10741657 and rs10766197, with respect to carriers of all risk alleles [28].

Furthermore, the rs10766197 CYP2R1 polymorphism is associated with risk of multiple sclerosis (MS) especially in men with disease progression [34], with coronary artery disease incidence [26] and with ischemic stroke [33].

\subsubsection{CYP27B1}

Bailey et al. found that CYP27B1 -1260C > A (rs10877012) and +2838T > C (rs4646536) polymorphisms were associated with the level reduction in the active calcidiol- $1 \alpha$-hydroxylase influencing the conversion of $25(\mathrm{OH}) \mathrm{D}$ to $1,25(\mathrm{OH}) \mathrm{D}$ and consequent increase in susceptibility to type 1 diabetes [36].

Moreover, CYP27B1 -1260 C variant is also associated with Graves' disease (GD), an autoimmune disease that causes an over-production of thyroid hormones, in Germans [37] and in the Polish population [35].

Kuhn et al. showed the lack of correlation between CYP27B1 rs10877012, 25(OH)D levels, and risk of cardiovascular disease incidence [38]; in hypertensive individuals, the CYP27B1 rs4646536 is associated with the incidence of congestive heart failure [44].

Finally, a study on the Australian and New Zealand multiple sclerosis (MS) patients showed that CYP27B1 rs703842 is strongly associated with MS disease [45] and these results have also been confirmed in the Swedish population [46].

Taken together, these data suggest an important regulatory function of CYP27B1 gene so that an SNP could regulate gene expression with a consequent effect on $1,25(\mathrm{OH})_{2} \mathrm{D}$ function and status.

\subsubsection{CYP24A1}

Several polymorphisms have been identified in CYP24A1, many of which are associated with the reduction in CYP24A1 enzyme activity [76,77].

Two vitamin D response elements (VDRE) are present in the CYP24A1 promoter region that regulates the transcription activity of this gene [78].

The polymorphism $\mathrm{T}>\mathrm{C}$, identified in position -279 within the distal vitamin D response element (VDRE2), results in decreased protein binding and CYP24A1 expression levels in cultured primary of human lymphocytes [76].

A study on the Amish population showed that CYP24A1 rs2762939 SNP is associated with coronary artery calcification (CAC), suggesting that vitamin D metabolism is involved in coronary atherosclerosis [47].

Moreover, Türkanoğlu Özçelik et al. analyzed the correlation between CYP24A1 rs927650 genotype and the risk of ischemic stroke together with hypertension, diabetes, smoking status, and obesity in the Turkish population [33]. The authors found that CT + TT alleles significantly increase the risk of stroke considering hypertensive versus normotensive, diabetic versus non-diabetic, smoker versus nonsmoker 
and obese versus non-obese subgroups [33]. Probably, the enzyme carrying this SNP increases the active vitamin D degradation, thus reducing its levels, with a higher risk for ischemic stroke.

\subsubsection{VDR}

Several SNPs have been identified in both non-coding and coding regions of the VDR; some of these, Fok I (rs2228570), Apa I (rs7975232), Bsm I (rs1544410), and Taq I (rs731236) have a physiological and pathological role in different pathologies such as cancer, diabetes and cardiovascular diseases [49-51]. Moreover, VDR knockout mice showed hypertension or cardiac hypertrophy and they are more susceptible to oncogene- or chemocarcinogen-induced tumors without developing cancer spontaneously [79].

A recent meta-analysis on 5259 cases with risk of coronary artery disease (CAD) and 1981 controls showed that Fok I, Bsm I, Taq I, and Apa I polymorphisms in the VDR might not be associated with CAD [52].

These data are in agreement with a Mendelian randomization study where there is no association between the reduction in levels of $25(\mathrm{OH}) \mathrm{D}$ and increased risk of heart disease or myocardial infarction [53].

Prabhakar et al. evaluated the association between Fok I, Apa I, Taq I and Bsm I variants and ischemic stroke in the Asian Indian population (313 ischemic stroke patients vs. 244 healthy controls) [20]. The authors found that only Fok I is associated with ischemic stroke in a gender-specific manner [20].

\subsection{Epigenetic}

Another intriguing topic is the epigenetic regulation mechanism of the genes involved in the vitamin D metabolism due to a DNA methylation process.

DNA methylation is an epigenetic mechanism characterized by the covalent attachment of a methyl group to the $\mathrm{C} 5$ position of cytosine residues in $\mathrm{CpG}$ dinucleotide (cytosine followed by guanine residue) [80,81]. CpG methylation does not change the primary DNA structure, but rather alters the chromatin structure, regulating the gene expression patterns. These changes are heritable between generations with a specific pattern tissue. Indeed, DNA methylation is involved in several biological process, including cell cycle, differentiation and genomic imprinting.

DNA regions with a relatively high $\mathrm{CpG}$ dinucleotide content are referred to as $\mathrm{CpG}$ islands [82] that are distributed in a non-random manner across the human genome and often span $5^{\prime}$ untranslated region (UTR), 3' UTR, promoter region and the first exon of protein-coding genes. The methylation of CpG islands usually acts to turn off (silence) transcription by recruiting histone deacetylases, thereby inducing the formation of inactive chromatin [83]. Generally, hypermethylation is often associated with a decreased gene expression, while hypo-methylation is associated with an increased gene expression [83], so mapping the methylation patterns of CpG sites is an important tool for understanding both normal and pathogenic gene expression events $[84,85]$.

In the contest of vitamin D metabolism, CYP2R1, CYP27B1, CYP24A1 and VDR have large CpG islands in their promoter regions and in the gene body [86,87]. Consequently, the DNA methylation of $\mathrm{CpG}$ sites in these regions can regulate the transcriptional repression of these genes.

CYP2R1 gene is located on chromosome11p15.2 (chr11:14899556-14913751) and the promoter region contains a $\mathrm{CpG}$ island that includes $77 \mathrm{CpG}$ sites between +850 and -20 with respect to the start site of the gene, in agreement with the UCSC Genome Browser Homepage (GRCh37/hg19) [87]. Genome-wide association studies on leukocytes DNA from 22 African American male youths showed high methylation levels of the CYP2R1 promoter region in individuals with severe vitamin D deficiency versus the control group [30]. After one year of supplementation with vitamin $D$, the CYP2R1 promoter showed a significantly hypomethylation [30].

In agreement with these data, Zhou et al. found that, in post-menopausal women, a methylation reduction in CYP2R1 after vitamin D supplementation [31], while Beckett et al. found, in 80 Australian 
subjects (principally women), that CYP2R1 methylation levels are negatively associated with plasma 25(OH)D [32].

Taken together, these data suggest that, when vitamin D serum levels are low, the CYP2R1 promoter is hypermethylated and that a vitamin D supplementation can contribute to modulating the methylation levels of this gene.

The CYP27B1 gene is located on 12q14.1 chromosome (chr12:58156117-58160976) and, in the promoter region, a CpG island (91 CpG sites) is present between +2120 and +976 positions with respect to the start site of the gene [88].

The promoter region contains a negative VDRE (nVDRE) that, through recruitment of both histone deacetylases (HDACs) and DNA methyltransferases (DNMTs), by VDR/retinoid X receptor (RXR) is responsible for 1,25-D3-dependent trans repression [89].

In different types of tumor, such as primary lymphoma, leukemia, choriocarcinoma and breast cancer cells, methylation levels of the CYP27B1 promoter region are increased when compared with normal cells [39-42].

Moreover, hypomethylation of the CYP27B1 gene positively influences the rate of body mass index (BMI) observed in obese children (82 obese children, age: 3-18 years) [43], while no methylation differences in this gene were found by previous studies [30-32]. CYP27B1 encodes for calcidiol- $1 \alpha$-hydroxylase, which acts at the level of the liver and kidneys so that the observed discrepancy in the relationship to plasma $25(\mathrm{OH}) \mathrm{D}$ could depend on the type of tissue analyzed.

The CYP24A1 gene is located on chromosome 20q13.2 (chr20:52769988-52790516) and its promoter region contains a CpG island (136 CpG sites) spanning between +1263 and -470 positions with respect to the start site of the gene [88]. Several regulatory sequences are located within this genomic region, including two VDREs (VDRE 1 and VDRE 2), a vitamin-stimulating element (VSE) and SP1-binding sites [86].

DNA methylation of CYP24A1 is highly variable and tissue-specific, both in health and diseases [41,48].

Beckett et al. according with Zhou et al. reported that CYP24A1 methylation levels are negatively associated with plasma levels of $25(\mathrm{OH}) \mathrm{D}$ [31,32], but, when correcting for vitamin $\mathrm{D}$ intake, this correlation is lost, suggesting that methylation levels of CYP24A1 are influenced by its response to increased availability of plasma 25(OH)D.

The VDR gene, located on the chromosome 12q13.11 (chr12:48235320-48298814), contains four potential promoter regions that are well-conserved [90]. One of the most studied of these promoters contains a CpG island ( 71 CpG sites) spanning between +168 and +723 positions with respect to the start site of the gene.

In some tumors, such as breast tumors, the methylation levels of the VDR gene are significantly higher compared with normal breast tissue [55], while in others, such as colon cancer or parathyroid tumors, there are no differences in the methylation levels of $V D R[54,56]$.

In peripheral blood (PBCs) cells from healthy subjects, the VDR promoter methylation is positively associated with plasma 25(OH)D status [32]. Indeed, a hypermethylation of VDR in response to high plasma levels of $25(\mathrm{OH}) \mathrm{D}$ suggests a regulation mechanism based on a negative feedback loop, where a greater availability of the ligand reduced the expression of the receptor to maintain homeostasis of vitamin D metabolism.

Finally, few studies investigated the association between vitamin D status and global DNA methylation, producing controversial data [91,92].

\section{Vitamin D and Stroke}

A study from Poole et al. [59] concluded that reduced 25(OH) D $(<20 \mathrm{ng} / \mathrm{mL})$ was found in $77 \%$ of 44 patients analyzed within 30 days of their first-ever stroke. They hypothesized that the vitamin D deficiency was probably present before the stroke, given that the biological half-life of $25(\mathrm{OH}) \mathrm{D}$ is about 3 weeks and an acute reduction in $25(\mathrm{OH}) \mathrm{D}$ due to a decline in hormone synthesis or existing stores 
seemed impossible for the time between stroke event and 25(OH)D sampling. In a successive review, Liu et al. sustained that, among the new strategies to prevent stroke, there was administration of vitamin D [57]. Supplementation of this vitamin aimed to preserve a serum concentration of $25(\mathrm{OH}) \mathrm{D}$ above $30 \mathrm{ng} / \mathrm{mL}$ in the patient after a stroke insult, as well as in subjects at high risk of stroke, and was suggested to be a promising and protective therapy [57].

A review from Pilz et al. [16] outlined the possible pathways that match the vitamin D deficiency with increased stroke risk. Arterial hypertension is the principal risk factor for stroke and was associated with low vitamin levels; the mechanism seems related to the renin-angiotensin-aldosterone system, but also to the prevention of hyperparathyroidism, renoprotective and anti-inflammatory effects and to vasculoprotective properties.

Moreover, vitamin D deficiency is related to an augmented risk for type 2 diabetes mellitus [66]. Other risk factors for ischemic cerebrovascular events are atherosclerosis, prothrombotic states, secondary hyperparathyroidism, and inflammation.

More recently, Muscogiuri et al. deepened the role of Vitamin D deficiency in atherosclerosis, myocardial infarction and stroke, explaining the mechanism hypothesis together with a detailed description of all animal model studies [60].

In a large study cohort, in the Copenaghen City heart study and meta-analysis, Brøndum et al. [61] evaluated 10,170 individuals and, during a 21 years follow-up, observed that a total of 1256 developed ischemic stroke. When comparing subjects with severe vitamin D deficiency $(10 \mathrm{ng} / \mathrm{mL})$ to individuals with optimal vitamin D status $(30.0 \mathrm{ng} / \mathrm{mL})$, the multivariate adjusted hazard ratio of ischemic stroke was 1.36 (1.09-1.70). The vitamin D concentrations were not associated with the risk of hemorrhagic stroke. This result was confirmed by a meta-analysis that compared the lowest vs. highest quartile of $25(\mathrm{OH}) \mathrm{D}$; the multivariate-adjusted odds ratio of ischemic stroke was $1.54(1.43-1.65)$ with a corresponding hazard ratio of $1.46(1.35-1.58)$ in prospective studies [61].

Zhou et al. published an interesting systematic review and meta-analysis, including 19 studies exploring the possible association of vitamin D with risk of stroke [64]. The meta-analysis sustained the hypothesis that lower vitamin D status is associated with an increased risk of ischemic, but not hemorrhagic, stroke (relative risk $=2.45,95 \%$ CI:1.56-3.86).

In particular, one study presented in this meta-analyses showed an association of Vitamin D deficiency with stroke risk, without differences by race [62].

Two studies not included in this metanalysis deserve to be cited. One is the Ludwigshafen Risk and Cardiovascular Health (LURIC) study [63], which analyzed more than 3000 patients followed-up for 8 years. In this study, low levels of 25(OH)D and 1,25(OH)2D were shown to be predictive of fatal stroke [63]. The second is a study on vitamins as stroke predictors in elderly; this study showed that low vitamin D intake and low 1,25(OH)2D serum levels implied a major stroke risk [65].

Observational studies suggest that vitamin D may protect against stroke, but a recent important randomized, double-blind, placebo-controlled study (VITAL Study) on 25,871 subjects revealed that vitamin D3 (200 IU/days) supplementation does not reduce cardiovascular events, including stroke [58] (Table 1).

\section{Vitamin D and Post Stroke Recovery: Focus on Rehabilitation}

Is there a link between Vitamin D status and rehabilitation outcome in post-stroke patients? May patients undergoing rehabilitation benefit from sufficient vitamin D status considering its involvement in neurological, psychological, cognitive and musculoskeletal function?

Post-stroke patients often exhibit vitamin D deficiency that could be due to scarce mobility, absent or decreased sunlight exposure, inadequate diet or difficulty swallowing (dysphagia) [68]. The prevalence of dysphagia after stroke is $41 \%$ in the neurorehabilitation unit [93].

Several biochemical and neurophysiological aspects regarding neuronal cell activities, neurochemical and neuroimmunological processes, beyond the musculoskeletal system, have a relationship with the regulation and modulation of vitamin D levels. All these aspects are the main 
vitamin-D-dependent contributors to outcomes in patients with stroke undergoing rehabilitation treatment (Figure 2).

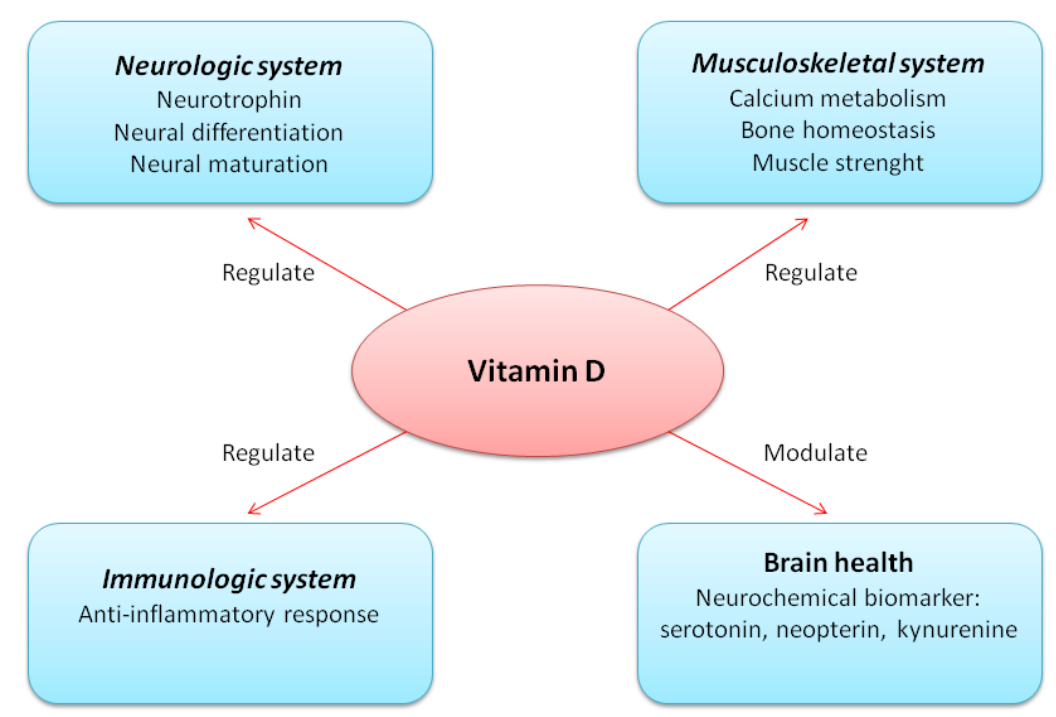

Figure 2. Role (regulation and modulation) of Vitamin D in neurologic, immunologic, musculoskeletal systems and brain health, that contributes to outcomes in patients with stroke undergoing rehabilitation treatment.

\subsection{Vitamin D and Outcome of Stroke}

Many studies investigated the relationship between Vitamin D levels and general outcome of stroke in post stroke patients, without specifying whether patients underwent rehabilitation treatment.

A very recent meta-analysis [11] investigated the prognostic utility of serum $25(\mathrm{OH}) \mathrm{D}$ in patients with stroke (ischemic stroke, but not hemorrhagic) in terms of functional outcome, all-cause mortality and recurrence of stroke. Of the 429 articles found, only 11 articles were included which reported all the necessary data. Reported risk estimates with continuous $25(\mathrm{OH}) \mathrm{D}$ values were not included. The meta-analysis explored: a. the association of lowest $25(\mathrm{OH}) \mathrm{D}$ level with a higher risk of poor functional outcome (five studies; Relative Risk: 1.86; 95\% CI 1.16-2.98); b. an increased risk of all-cause mortality (five studies; Relative Risk: 3.56; 95\% CI 1.54-8.25). c. the recurrence of stroke (three studies; Relative Risk: 5.49; 95\% CI 2.69-11.23).

Note that, as the author underlined, the reviewed papers were heterogeneous due to differences in clinical setting, follow-up duration, stages or types of stroke, and only four of them considered the impact of vitamin D deficiency on functional outcome using the modified Rankin scale (a very simple scale used to measure the degree of disability in patients who have had a stroke).

Turetsky et al. [70] reported that patients with lower vitamin D levels at admission showed increased mortality after one year from insult.

Another recent study from Alfieri et al. [71], including 168 acute ischemic stroke patients and 118 controls, reported that patients had lower $25(\mathrm{OH}) \mathrm{D}$ levels, with higher frequency of vitamin $\mathrm{D}$ deficiency with respect to control. More importantly, 25(OH)D levels had a negative correlation with modified ranking scale after three-months follow-up independently of age, sex and neurological deficit, so Vitamin D deficiency could be deemed as an independent biomarker of ischemic stroke. As for the authors' declaration, some limitations are included in this study, such as the absence of important data including calcium concentration, sun exposure, dietary intake of vitamin D and outdoor physical activity.

Markisic et al. [14] analyzed the influence of Vitamin D levels on functional outcomes after first-ever ischemic stroke, at 3 months and 6 months from stroke. The functional outcomes were evaluated and 
measured with the Barthel index and Modified Ranking Scale, including scale of performance in ability of daily living, and neurological disability, respectively. At admission, the NIH Stroke Scale (NIHSS) negatively correlated with vitamin $\mathrm{D}$, suggesting that major impairment after stroke correlated with lower levels of vitamin D; adjusting for age and the baseline NIHSS values, a trend in correlations were found between functional outcomes at all timepoints (Barthel index and modified ranking scale) and vitamin D levels. Authors highlighted that they included only surviving patients in the final analysis, so no data about vitamin D levels in dead patients were reported, not allowing a correct evaluation [14]. Moreover, a noteworthy aspect of this study [14] was that vitamin D level increased during the follow-up, whereas no supplementations were administered; authors properly suggested that secondary dietary changes could have contributed to these results which they did not evaluate.

A special case is the association between vitamin D status and cognitive impairment in acute ischemic stroke patients. In fact, a recent study suggested the involvement of vitamin D deficiency in cognitive and mood disorders in the elderly [94], in quality of life in postmenopausal women [95], and in general anxiety disorders [96]. In a prospective cohort study on 354 patients, vitamin D deficiency was independently associated with the development of cognitive impairment measured by Mini-Mental State Examination [69]. In a previous retrospective study, Yalbuzdag et al. [13] found that in 120 stroke patients included in a neurological rehabilitation program, 25(OH)D level correlated with cognitive impairment for MMSE score in the ischemic group.

\subsection{Supplementation of Vitamin D and Post Stroke Recovery}

A randomized controlled open-label trial from Gupta et al. [72] analyzed ischemic stroke survivors for serum 25(OH)D levels in relation with outcome measured with Modified Rankin Scale for neurological disability. The study screened 73 stroke survivors, with a final number of 53 patients with insufficient baseline 25(OH)D levels. Patients were then divided randomly into two arms: the intervention arm $(n=25)$ received vitamin $D$ and calcium supplementation together with usual care and the control arm $(n=28)$ received only usual care. In the intervention arm, the proportion of patients achieving a good outcome was higher and the survival probability was greater compared with the control arm. These results point towards a potential benefit of calcium and vitamin D supplementation.

Kim et al. [67] analyzed vitamin D levels in 23 patients from 1 to 4 weeks after stroke onset (defined subacute group) and 28 patients 4 weeks from stroke insult (defined chronic group).

They further subdivided patients based on ambulating capacity (ambulating vs. non-deambulating, by means of modified ranking scale) and feeding methods (total parenteral nutrition, enteral nutrition-oral or tube feeding). In the chronic group, $25(\mathrm{OH}) \mathrm{D}$ levels were lower than in the subacute group and below normal reference range. Moreover, in subacute group 25(OH)D levels were lower in patients with parenteral nutrition with respect to patients with enteral nutrition, while among chronic patients, $25(\mathrm{OH}) \mathrm{D}$ levels were higher in patients capable of walking independently. These results suggest supplementation of vitamin $\mathrm{D}$, especially in non-deambulating patients and total parenteral nutrition.

More recently, a randomized, double-blind, placebo-controlled trial was conducted by Momosaki et al. [73] on 100 post-stroke patients (primary outcome: a gain in the Barthel index score at week 8 from onset). Authors did not report any differences between the group receiving vitamin D3 (2000 IU/day) and placebo group. This study showed an important limitation: serum 25(OH)D levels were not measured at admission, nor after 8 weeks (they consider that all elderly patients undergoing rehabilitation probably have vitamin $\mathrm{D}$ deficiency). This seems quite unusual considering that this analysis is unique in individuating actual vitamin D deficiency. In our opinion, this study could be influenced by patients with a normal value of vitamin D levels.

\subsection{Vitamin D and Rehabilitation after Stroke}

There is only a relatively old review [3] in which the authors report that vitamin D deficiency is rarely documented in the rehabilitation literature. This study was done on 107 articles, narrowed 
to 51, focusing on vitamin D levels and musculoskeletal manifestations, like musculoskeletal pain and muscle weakness. Musculoskeletal pain is often seen in rehabilitation settings, where patients arrive after a long hospitalization and in a poor nutritional status, often including vitamin D deficiency. As reported by the authors, numerous studies have shown improvements in muscle strength after supplementation of vitamin $\mathrm{D}$, with an improvement in outcome measurements of lower-extremity functions like walking tests or sit-to-stand tests [3].

Kiebzak et al. [12] determined the association between vitamin D status, baseline function, and short-term inpatient recovery after rehabilitation in 100 heterogeneous patients (including 15 post-stroke patients). At admission, $80 \%$ of patients were highly vitamin-D-deficient $(25(\mathrm{OH}) \mathrm{D}<0.8 \mathrm{ng} / \mathrm{mL}$ or) with $94 \%$ below the recommended minimum of $32 \mathrm{ng} / \mathrm{mL}$. Moreover, a weak but significant association with a low total Functional Independence Measurement (FIM) score at admission and at discharge was found. Patients with a $25(\mathrm{OH}) \mathrm{D}$ greater than median value of $16.5 \mathrm{ng} / \mathrm{mL}$ had a significantly higher mean FIM score than patients with values below the median. Authors suggest that, in patients that underwent rehabilitation treatment, suboptimal vitamin D should be evaluated by means of routine analysis, and should be corrected by supplementation [12].

Yalbuzdag et al. [13] came to the same conclusions, reporting that high levels of 25(OH)D were associated with greater functional gain during the rehabilitation protocol treatment.

A very recent multi-center study is the "Safari study", on a population of 420 Italian and Spanish older adults admitted to three geriatric rehabilitation unit, after orthopedic events or stroke $(n=138)$ [15]. Patients were divided in quartiles based on the $25(\mathrm{OH}) \mathrm{D}$ levels, and the outcomes of rehabilitation were: absolute functional gain (variation of Barthel index between discharge and admission) and ability to walk both 3 months after admission. A non-linear relationship between vitamin $\mathrm{D}$ and absolute functional gain was found, with a stronger association for $25(\mathrm{OH}) \mathrm{D}$ concentration $<16 \mathrm{ng} / \mathrm{mL}$. In particular, patients in the third quartile Q3 (serum 25(OH)D: $11.5-18.2 \mathrm{ng} / \mathrm{mL}$ ) had the best absolute functional gain and ability to walk compared to patients in the first quartile Q1 (serum $25(\mathrm{OH}) \mathrm{D}: \leq 6 \mathrm{ng} / \mathrm{mL})$. Authors suggested the importance of considering a non-linear relationship between $25(\mathrm{OH}) \mathrm{D}$ and functional outcomes; therefore, using linear models as a continuous variable may be not correct, as in the study of Markisic et al. [14].

Finally a recent meta-analysis from Chen et al. [74] reported malnutrition as an important risk factor for stroke that can influence the general status of patients during post-stroke rehabilitation, and the rehabilitation outcome. Stroke patients, in fact, undergo a long period of rehabilitation, in some cases for 1 year after the onset. Motor disability, cognitive impairment, psychological aspects and dysphagia contribute to a general status of malnutrition. Low vitamin D levels can be also due to reduced nutrition, influencing the outcome of rehabilitation and contributing to a poor recovery (Table 1).

\section{Conclusions and Future Perspective}

In this review, we reported papers which presented a relationship between vitamin D levels and outcome of stroke; in particular, we wanted to focus on papers in which rehabilitation outcome after stroke and vitamin D levels were analyzed. These latter results are preliminary, come from very heterogeneous studies and need further detailed study.

Therefore, our literature revision showed that vitamin D metabolism is associated with post-stroke recovery with some limitations: 1 . the studies are few, and often analyzed small and not homogeneous samples; 2 . the rehabilitation treatments are heterogeneous (different outcome) and not well-described in terms of duration of treatment, making it difficult to match the various results. 3 . an accurate nutritional status, as well as detection during treatment, is often not considered, confounding the vitamin D actual status.

An important and emerging aspect shown in this review concerns single-nucleotide polymorphisms and promoter methylation in genes involved in vitamin D metabolism that seem to affect circulating vitamin D levels. This evidence opens a new and important field that could have a 
crucial role for stroke patients undergoing rehabilitation treatment. In fact, low vitamin D levels in stroke patients, due to malnutrition, could also be influenced by an individual genetic asset and an individual epigenetic response to the rehabilitation. There is a genetic predisposition to assimilate and metabolize vitamin $\mathrm{D}$, but the data presented are obtained from published studies that turn out to be inconclusive and contradictory. Probably, ethnic background, sample size and the uniformity of cases vs. controls can influence the results of a clear relationship between CYP2R1, CYP27B1, CYP24A1 and $V D R$ polymorphisms and methylation with disease susceptibility. Indeed, clinical usage of these data is not applicable and further research is needed in order to clarify the mechanism responsible for association between serum $25(\mathrm{OH}) \mathrm{D}$ concentrations and genetic and epigenetic determinants.

Therefore, from this it is clear that the association between vitamin D levels, genetic factors and rehabilitation after stroke is a matter of debate and is an open issue which deserves more studies. Moreover, we suggest, in the future, in post-stroke patients undergoing rehabilitation treatment:

(a) to measure the $25(\mathrm{OH}) \mathrm{D}$ levels at admission and post-rehabilitation;

(b) to identify the presence/absence of CYP2R1, CYP27B1, CYP24A1 and VDR polymorphisms;

(c) to analyze the methylation levels of these genes pre- and post-rehabilitation treatment.

Author Contributions: Conceptualization, M.S. (Mariacristina Siotto), M.S. (Massimo Santoro) and I.A.; Writing-original draft preparation, M.S. (Mariacristina Siotto) and M.S. (Massimo Santoro); writing- review and editing, M.S. (Mariacristina Siotto), M.S. (Massimo Santoro); supervision, I.A. All authors have read and agreed to the published version of the manuscript.

Funding: This research received no external funding.

Acknowledgments: We acknowledge Claudia Loreti for precious help in literature revision.

Conflicts of Interest: The authors declare no conflict of interest.

\section{References}

1. Mozaffarian, D.; Benjamin, E.J.; Go, A.S.; Arnett, D.K.; Blaha, M.J.; Cushman, M.; Das, S.R.; De Ferranti, S.; Després, J.P.; Fullerton, H.J.; et al. Executive summary: Heart disease and stroke statistics-2016 update: A Report from the American Heart Association. Circulation 2016, 133, 447-454. [CrossRef]

2. Lim, H.; Choue, R. Impact of nutritional status and dietary quality on stroke: Do we need specific recommendations? Eur. J. Clin. Nutr. 2013, 67, 548-554. [CrossRef]

3. Heath, K.M.; Elovic, E.P. Vitamin D Deficiency. Am. J. Phys. Med. Rehabil. 2006, 85, 916-923. [CrossRef]

4. Mousavi, S.E.; Amini, H.; Heydarpour, P.; Amini Chermahini, F.; Godderis, L. Air pollution, environmental chemicals, and smoking may trigger vitamin D deficiency: Evidence and potential mechanisms. Environ. Int. 2019, 122, 67-90. [CrossRef]

5. Holick, M.F. The vitamin D deficiency pandemic: Approaches for diagnosis, treatment and prevention. Rev. Endocr. Metab. Disord. 2017, 18, 153-165. [CrossRef]

6. Christodoulou, S.; Goula, T.; Ververidis, A.; Drosos, G. Vitamin D and Bone Disease. Biomed Res. Int. 2013, 2013, 1-6. [CrossRef]

7. Willems, H.M.E.; van den Heuvel, E.G.H.M.; Schoemaker, R.J.W.; Klein-Nulend, J.; Bakker, A.D. Diet and Exercise: A Match Made in Bone. Curr. Osteoporos. Rep. 2017, 15, 555-563. [CrossRef]

8. Wang, T.J.; Pencina, M.J.; Booth, S.L.; Jacques, P.F.; Ingelsson, E.; Lanier, K.; Benjamin, E.J.; D'Agostino, R.B.; Wolf, M.; Vasan, R.S. Vitamin D Deficiency and Risk of Cardiovascular Disease. Circulation 2008, 117, 503-511. [CrossRef]

9. Plum, L.A.; DeLuca, H.F. Vitamin D, disease and therapeutic opportunities. Nat. Rev. Drug Discov. 2010, 9, 941-955. [CrossRef]

10. Wang, S. Epidemiology of vitamin D in health and disease. Nutr. Res. Rev. 2009, 22, 188-203. [CrossRef]

11. Liu, H.; Wang, J.; Xu, Z. Prognostic utility of serum 25-hydroxyvitamin D in patients with stroke: A meta-analysis. J. Neurol. 2019. [CrossRef]

12. Kiebzak, G.M.; Moore, N.L.; Margolis, S.; Hollis, B.; Kevorkian, C.G. Vitamin D Status of Patients Admitted to a Hospital Rehabilitation Unit. Am. J. Phys. Med. Rehabil. 2007, 86, 435-445. [CrossRef] 
13. Yalbuzdag, S.A.; Sarifakioglu, B.; Afsar, S.I.; Celik, C.; Can, A.; Yegin, T.; Senturk, B.; Guzelant, A.Y. Is 25(OH)D Associated with Cognitive Impairment and Functional Improvement in Stroke? A Retrospective Clinical Study. J. Stroke Cerebrovasc. Dis. 2015, 24, 1479-1486. [CrossRef]

14. Markišić, M.; Pavlović, A.M.; Pavlović, D.M. The Impact of Homocysteine, Vitamin B12, and Vitamin D Levels on Functional Outcome after First-Ever Ischaemic Stroke. Biomed Res. Int. 2017, 2017, 1-6. [CrossRef]

15. Lelli, D.; Pérez Bazan, L.M.; Calle Egusquiza, A.; Onder, G.; Morandi, A.; Ortolani, E.; Mesas Cervilla, M.; Pedone, C.; Inzitari, M. 25(OH) vitamin D and functional outcomes in older adults admitted to rehabilitation units: The safari study. Osteoporos. Int. 2019, 30, 887-895. [CrossRef]

16. Pilz, S.; Tomaschitz, A.; Drechsler, C.; Zittermann, A.M.; Dekker, J.; Marz, W. Vitamin D Supplementation: A Promising Approach for the Prevention and Treatment of Strokes. Curr. Drug Targets 2011, 12, 88-96. [CrossRef]

17. Wikvall, K. Cytochrome P450 enzymes in the bioactivation of vitamin D to its hormonal form (review). Int. J. Mol. Med. 2001, 7, 201-209. [CrossRef]

18. Prosser, D.E.; Jones, G. Enzymes involved in the activation and inactivation of vitamin D. Trends Biochem. Sci. 2004, 29, 664-673. [CrossRef]

19. Maalouf, N.M. The noncalciotropic actions of vitamin D: Recent clinical developments. Curr. Opin. Nephrol. Hypertens. 2008, 17, 408-415. [CrossRef]

20. Prabhakar, P.; Majumdar, V.; Kulkarni, G.B.; Christopher, R. Genetic variants of vitamin D receptor and susceptibility to ischemic stroke. Biochem. Biophys. Res. Commun. 2015, 456, 631-636. [CrossRef]

21. Gezen-Ak, D.; Dursun, E.; Yilmazer, S. Vitamin D inquiry in hippocampal neurons: Consequences of vitamin D-VDR pathway disruption on calcium channel and the vitamin D requirement. Neurol. Sci. 2013, 34, 1453-1458. [CrossRef]

22. Ross, C.A.; Taylor, C.L.; Yaktime, A.L.; Del Valle, H.B. Dietary Reference Intakes for Calcium and Vitamin; Committee to Review Dietary Reference Intakes for Vitamin D and Calcium; Institute of Medicine, National Academies Press: Washington, DC, USA, 2011.

23. Holick, M.F.; Binkley, N.C.; Bischoff-Ferrari, H.A.; Gordon, C.M.; Hanley, D.A.; Heaney, R.P.; Murad, M.H.; Weaver, C.M. Endocrine Society Evaluation, treatment, and prevention of vitamin D deficiency: An Endocrine Society clinical practice guideline. J. Clin. Endocrinol. Metab. 2011, 96, 1911-1930. [CrossRef]

24. Romagnoli, E.; Carnevale, V.; Biondi, P.; Minisola, S. Vitamin D supplementation: When and how? J. Endocrinol. Invest. 2014, 37, 603-607. [CrossRef]

25. Slater, N.A.; Rager, M.L.; Havrda, D.E.; Harralson, A.F. Genetic Variation in CYP2R1 and GC Genes Associated with Vitamin D Deficiency Status. J. Pharm. Pract. 2017, 30, 31-36. [CrossRef]

26. Hassanein, S.I.; Abu El Maaty, M.A.; Sleem, H.M.; Gad, M.Z. Triangular relationship between single nucleotide polymorphisms in the CYP2R1 gene (rs10741657 and rs12794714), 25-hydroxyvitamin d levels, and coronary artery disease incidence. Biomarkers 2014, 19, 488-492. [CrossRef]

27. Arabi, A.; Khoueiry-Zgheib, N.; Awada, Z.; Mahfouz, R.; Al-Shaar, L.; Hoteit, M.; Rahme, M.; Baddoura, R.; Halabi, G.; Singh, R.; et al. CYP2R1 polymorphisms are important modulators of circulating 25-hydroxyvitamin D levels in elderly females with vitamin insufficiency, but not of the response to vitamin $\mathrm{D}$ supplementation. Osteoporos. Int. 2017, 28, 279-290. [CrossRef]

28. Nissen, J.; Rasmussen, L.B.; Ravn-Haren, G.; Andersen, E.W.; Hansen, B.; Andersen, R.; Mejborn, H.; Madsen, K.H.; Vogel, U. Common Variants in CYP2R1 and GC Genes Predict Vitamin D Concentrations in Healthy Danish Children and Adults. PLoS ONE 2014, 9, e89907. [CrossRef]

29. Duan, L.; Xue, Z.; Ji, H.; Zhang, D.; Wang, Y. Effects of CYP2R1 gene variants on vitamin D levels and status: A systematic review and meta-analysis. Gene 2018, 678, 361-369. [CrossRef]

30. Zhu, H.; Wang, X.; Shi, H.; Su, S.; Harshfield, G.A.; Gutin, B.; Snieder, H.; Dong, Y. A Genome-Wide Methylation Study of Severe Vitamin D Deficiency in African American Adolescents. J. Pediatr. 2013, 162, 1004-1009.e1. [CrossRef]

31. Zhou, Y.; Zhao, L.J.; Xu, X.; Ye, A.; Travers-Gustafson, D.; Zhou, B.; Wang, H.W.; Zhang, W.; Lee Hamm, L.; Deng, H.W.; et al. DNA methylation levels of CYP2R1 and CYP24A1 predict vitamin D response variation. J. Steroid Biochem. Mol. Biol. 2014, 144, 207-214. [CrossRef]

32. Beckett, E.L.; Duesing, K.; Martin, C.; Jones, P.; Furst, J.; King, K.; Niblett, S.; Yates, Z.; Veysey, M.; Lucock, M. Relationship between methylation status of Vitamin D-related genes, Vitamin D levels, and methyl-donor biochemistry. J. Nutr. Intermed. Metab. 2016, 6, 8-15. [CrossRef] 
33. Türkanoğlu Özçelik, A.; Öner, T.; Can Demirdöğen, B.; Bek, V.S.; Demirkaya, Ş.; Adalı, O. Genetic polymorphisms of vitamin D3 metabolizing CYP24A1 and CYP2R1 enzymes in Turkish patients with ischemic stroke. Neurol. Res. 2018, 40, 364-371. [CrossRef] [PubMed]

34. Scazzone, C.; Agnello, L.; Ragonese, P.; Lo Sasso, B.; Bellia, C.; Bivona, G.; Schillaci, R.; Salemi, G.; Ciaccio, M. Association of CYP2R1 rs10766197 with MS risk and disease progression. J. Neurosci. Res. 2018, 96, 297-304. [CrossRef]

35. Kurylowicz, A.; Badenhoop, K. CYP27B1 gene polymorphism is associated with Graves' disease in a Polish population study. Thyroid 2005, 15, 1107-1108. [CrossRef]

36. Bailey, R.; Cooper, J.D.; Zeitels, L.; Smyth, D.J.; Yang, J.H.M.; Walker, N.M.; Hyppönen, E.; Dunger, D.B.; Ramos-Lopez, E.; Badenhoop, K.; et al. Association of the vitamin D metabolism gene CYP27B1 with type 1 diabetes. Diabetes 2007, 56, 2616-2621. [CrossRef]

37. Lopez, E.R.; Zwermann, O.; Segni, M.; Meyer, G.; Reincke, M.; Seissler, J.; Herwig, J.; Usadel, K.H.; Badenhoop, K. A promoter polymorphism of the CYP27B1 gene is associated with Addison's disease, Hashimoto's thyroiditis, Grave's disease and type 1 diabetes mellitus in Germans. Eur. J. Endocrinol. 2004, 151, 193-197. [CrossRef]

38. Kühn, T.; Kaaks, R.; Teucher, B.; Hirche, F.; Dierkes, J.; Weikert, C.; Katzke, V.; Boeing, H.; Stangl, G.I.; Buijsse, B. Plasma 25-Hydroxyvitamin D and Its Genetic Determinants in Relation to Incident Myocardial Infarction and Stroke in the European Prospective Investigation into Cancer and Nutrition (EPIC)-Germany Study. PLoS ONE 2013, 8, e69080. [CrossRef]

39. Lagger, G.; Doetzlhofer, A.; Schuettengruber, B.; Haidweger, E.; Simboeck, E.; Tischler, J.; Chiocca, S.; Suske, G.; Rotheneder, H.; Wintersberger, E.; et al. The Tumor Suppressor p53 and Histone Deacetylase 1 Are Antagonistic Regulators of the Cyclin-Dependent Kinase Inhibitor p21/WAF1/CIP1 Gene. Mol. Cell. Biol. 2003, 23, 2669-2679. [CrossRef]

40. Wjst, M.; Heimbeck, I.; Kutschke, D.; Pukelsheim, K. Epigenetic regulation of vitamin D converting enzymes. J. Steroid Biochem. Mol. Biol. 2010, 121, 80-83. [CrossRef]

41. Novakovic, B.; Sibson, M.; Ng, H.K.; Manuelpillai, U.; Rakyan, V.; Down, T.; Beck, S.; Fournier, T.; Evain-Brion, D.; Dimitriadis, E.; et al. Placenta-specific methylation of the vitamin D 24-hydroxylase gene. Implications for feedback autoregulation of active vitamin D levels at the fetomaternal interface. J. Biol. Chem. 2009, 284, 14838-14848. [CrossRef]

42. Shi, H.; Yan, P.S.; Rahmatpanah, F.; Caldwell, C.W.; Huang, T.H.M.; Chen, C.M.; Lofton-Day, C. Expressed $\mathrm{CpG}$ island sequence tag microarray for dual screening of DNA hypermethylation and gene silencing in cancer cells. Cancer Res. 2002, 62, 3214-3220.

43. Ács, O.; Péterfia, B.; Hollósi, P.; Luczay, A.; Török, D.; Szabó, A. Methylation Status of CYP27B1 and IGF2 Correlate to BMI SDS in Children with Obesity. Obes. Facts 2017, 10, 353-362. [CrossRef]

44. Wilke, R.A.; Simpson, R.U.; Mukesh, B.N.; Bhupathi, S.V.; Dart, R.A.; Ghebranious, N.R.; McCarty, C.A. Genetic variation in CYP27B1 is associated with congestive heart failure in patients with hypertension. Pharmacogenomics 2009, 10, 1789-1797. [CrossRef]

45. Bahlo, M.; Booth, D.R.; Simon, A.B.; Brown, M.A.; Foote, S.J.; Griffiths, L.R.; Kilpatrick, T.J.; Lechner-Scott, J.; Moscato, P.; Perreau, V.M.; et al. Genome-wide association study identifies new multiple sclerosis susceptibility loci on chromosomes 12 and 20. Nat. Genet. 2009, 41, 824-828.

46. Sundqvist, E.; Bäärnhielm, M.; Alfredsson, L.; Hillert, J.; Olsson, T.; Kockum, I. Confirmation of association between multiple sclerosis and CYP27B1. Eur. J. Hum. Genet. 2010, 18, 1349-1352. [CrossRef]

47. Shen, H.; Bielak, L.F.; Ferguson, J.F.; Streeten, E.A.; Yerges-Armstrong, L.M.; Liu, J.; Post, W.; O'Connell, J.R.; Hixson, J.E.; Kardia, S.L.R.; et al. Association of the vitamin D metabolism gene CYP24A1 with coronary artery calcification. Arterioscler. Thromb. Vasc. Biol. 2010, 30, 2648-2654. [CrossRef]

48. Luo, W.; Karpf, A.R.; Deeb, K.K.; Muindi, J.R.; Morrison, C.D.; Johnson, C.S.; Trump, D.L. Epigenetic regulation of vitamin D 24-hydroxylase/CYP24A1 in human prostate cancer. Cancer Res. 2010, 70, 5953-5962. [CrossRef]

49. Vélayoudom-Céphise, F.L.; Larifla, L.; Donnet, J.P.; Maimaitiming, S.; Deloumeaux, J.; Blanchet, A.; Massart, C.; Munoz-Bellili, N.; Merle, S.; Chout, R.; et al. Vitamin D deficiency, vitamin D receptor gene polymorphisms and cardiovascular risk factors in Caribbean patients with type 2 diabetes. Diabetes Metab. 2011, 37, 540-545. [CrossRef] 
50. Rai, V.; Abdo, J.; Agrawal, S.; Agrawal, D.K. Vitamin D receptor polymorphism and cancer: An update. Anticancer Res. 2017, 37, 3991-4003.

51. Sygitowicz, G.; Pera, Ł.; Sitkiewicz, D. Vitamin D receptor (VDR) polymorphism and the risk of cardiovascular events. Kardiol. Pol. 2014, 72, 64-66. [CrossRef]

52. Alizadeh, S.; Djafarian, K.; Alizadeh, H.; Mohseni, R.; Shab-Bidar, S. Common variants of Vitamin D receptor gene polymorphisms and susceptibility to coronary artery disease: A systematic review and meta-Analysis. J. Nutrigenet. Nutrgenom. 2017, 10,9-18. [CrossRef]

53. Brøndum-Jacobsen, P.; Benn, M.; Afzal, S.; Nordestgaard, B.G. No evidence that genetically reduced 25-hydroxyvitamin D is associated with increased risk of ischaemic heart disease or myocardial infarction: A Mendelian randomization study. Int. J. Epidemiol. 2015, 44, 651-661. [CrossRef]

54. Höbaus, J.; Fetahu, I.S.; Khorchide, M.; Manhardt, T.; Kallay, E. Epigenetic regulation of the 1,25-dihydroxyvitamin D3 24-hydroxylase (CYP24A1) in colon cancer cells. J. Steroid Biochem. Mol. Biol. 2013, 136, 296-299. [CrossRef]

55. Marik, R.; Fackler, M.J.; Gabrielson, E.; Zeiger, M.A.; Sukumar, S.; Stearns, V.; Umbricht, C.B. DNA methylation-related vitamin D receptor insensitivity in breast cancer. Cancer Biol. Ther. 2010, 10, 44-53. [CrossRef]

56. Sulaiman, L.; Juhlin, C.C.; Nilsson, I.-L.; Fotouhi, O.; Larsson, C.; Hashemi, J. Global and gene-specific promoter methylation analysis in primary hyperparathyroidism. Epigenetics 2013, 8, 646-655. [CrossRef]

57. Liu, A.-J.; Guo, J.-M.; Xia, W.; Su, D.-F. New strategies for the prevention of stroke. Clin. Exp. Pharmacol. Physiol. 2010, 37, 265-271. [CrossRef]

58. Manson, J.E.; Cook, N.R.; Lee, I.-M.; Christen, W.; Bassuk, S.S.; Mora, S.; Gibson, H.; Gordon, D.; Copeland, T.; D'Agostino, D.; et al. Vitamin D Supplements and Prevention of Cancer and Cardiovascular Disease. N. Engl. J. Med. 2019, 380, 33-44. [CrossRef]

59. Poole, K.E.S.; Loveridge, N.; Barker, P.J.; Halsall, D.J.; Rose, C.; Reeve, J.; Warburton, E.A. Reduced Vitamin D in Acute Stroke. Stroke 2006, 37, 243-245. [CrossRef]

60. Muscogiuri, G.; Annweiler, C.; Duval, G.; Karras, S.; Tirabassi, G.; Salvio, G.; Balercia, G.; Kimball, S.; Kotsa, K.; Mascitelli, L.; et al. Vitamin D and cardiovascular disease: From atherosclerosis to myocardial infarction and stroke. Int. J. Cardiol. 2017, 230, 577-584. [CrossRef]

61. Brøndum-Jacobsen, P.; Nordestgaard, B.G.; Schnohr, P.; Benn, M. 25-Hydroxyvitamin D and symptomatic ischemic stroke: An Original Study and Meta-Analysis. Ann. Neurol. 2013, 73, 38-47. [CrossRef]

62. Judd, S.E.; Morgan, C.J.; Panwar, B.; Howard, V.J.; Wadley, V.G.; Jenny, N.S.; Kissela, B.M.; Gutiérrez, O.M. Vitamin D deficiency and incident stroke risk in community-living black and white adults. Int. J. Stroke 2016, 11, 93-102. [CrossRef]

63. Pilz, S.; Dobnig, H.; Fischer, J.E.; Wellnitz, B.; Seelhorst, U.; Boehm, B.O.; März, W. Low Vitamin D Levels Predict Stroke in Patients Referred to Coronary Angiography. Stroke 2008, 39, 2611-2613. [CrossRef]

64. Zhou, R.; Wang, M.; Huang, H.; Li, W.; Hu, Y.; Wu, T. Lower Vitamin D Status Is Associated with an Increased Risk of Ischemic Stroke: A Systematic Review and Meta-Analysis. Nutrients 2018, 10, 277. [CrossRef]

65. Makariou, S.E.; Michel, P.; Tzoufi, M.S.; Challa, A.; Milionis, H.J. Vitamin D and stroke: Promise for prevention and better outcome. Curr. Vasc. Pharmacol. 2014, 12, 117-124. [CrossRef]

66. Pittas, A.G.; Lau, J.; Hu, F.B.; Dawson-Hughes, B. The Role of Vitamin D and Calcium in Type 2 Diabetes. A Systematic Review and Meta-Analysis. J. Clin. Endocrinol. Metab. 2007, 92, 2017-2029. [CrossRef]

67. Kim, K.; Cho, K.H.; Im, S.H.; Choi, J.; Yu, J.; Kim, M.Y. Decrement of Serum Vitamin D Level After Stroke. Ann. Rehabil. Med. 2017, 41, 944-950. [CrossRef]

68. Marsden, J.; Gibson, L.M.; Lightbody, C.E.; Sharma, A.K.; Siddiqi, M.; Watkins, C. Can early onset bone loss be effectively managed in post-stroke patients? An integrative review of the evidence. Age Ageing 2008, 37, 142-150. [CrossRef]

69. Chen, H.; Liu, Y.; Huang, G.; Zhu, J.; Feng, W.; He, J. Association between vitamin D status and cognitive impairment in acute ischemic stroke patients: A prospective cohort study. Clin. Interv. Aging 2018, 13, 2503-2509. [CrossRef]

70. Turetsky, A.; Goddeau, R.P.; Henninger, N. Low Serum Vitamin D Is Independently Associated with Larger Lesion Volumes after Ischemic Stroke. J. Stroke Cerebrovasc. Dis. 2015, 24, 1555-1563. [CrossRef] 
71. Alfieri, D.F.; Lehmann, M.F.; Oliveira, S.R.; Flauzino, T.; Delongui, F.; de Araújo, M.C.M.; Dichi, I.; Delfino, V.D.; Mezzaroba, L.; Simão, A.N.C.; et al. Vitamin D deficiency is associated with acute ischemic stroke, C-reactive protein, and short-term outcome. Metab. Brain Dis. 2017, 32, 493-502. [CrossRef]

72. Gupta, A.; Prabhakar, S.; Modi, M.; Bhadada, S.K.; Kalaivani, M.; Lal, V.; Khurana, D. Effect of Vitamin D and calcium supplementation on ischaemic stroke outcome: A randomised controlled open-label trial. Int. J. Clin. Pract. 2016, 70, 764-770. [CrossRef]

73. Momosaki, R.; Abo, M.; Urashima, M. Vitamin D Supplementation and Post-Stroke Rehabilitation: A Randomized, Double-Blind, Placebo-Controlled Trial. Nutrients 2019, 11, 1295. [CrossRef]

74. Chen, N.; Li, Y.; Fang, J.; Lu, Q.; He, L. Risk factors for malnutrition in stroke patients: A meta-analysis. Clin. Nutr. 2019, 38, 127-135. [CrossRef]

75. Ramos-Lopez, E.; Brück, P.; Jansen, T.; Herwig, J.; Badenhoop, K. CYP2R1 (vitamin D 25-hydroxylase) gene is associated with susceptibility to type 1 diabetes and vitamin D levels in Germans. Diabetes. Metab. Res. Rev. 2007, 23, 631-636. [CrossRef]

76. Roff, A.; Wilson, R.T. A novel SNP in a vitamin D response element of the CYP24A1 promoter reduces protein binding, transactivation, and gene expression. J. Steroid Biochem. Mol. Biol. 2008, 112, 47-54. [CrossRef]

77. Jacobs, E.T.; Van Pelt, C.; Forster, R.E.; Zaidi, W.; Hibler, E.A.; Galligan, M.A.; Haussler, M.R.; Jurutka, P.W. CYP24A1 and CYP27B1 polymorphisms modulate vitamin D metabolism in colon cancer cells. Cancer Res. 2013, 73, 2563-2573. [CrossRef]

78. Armbrecht, H.J.; Hodam, T.L.; Boltz, M.A.; Partridge, N.C.; Brown, A.J.; Kumar, V.B. Induction of the vitamin D 24-hydroxylase (CYP24) by 1,25-dihydroxyvitamin D3is regulated by parathyroid hormone in UMR106 osteoblastic cells. Endocrinology 1998, 139, 3375-3381. [CrossRef]

79. Bouillon, R.; Carmeliet, G.; Verlinden, L.; Van Etten, E.; Verstuyf, A.; Luderer, H.F.; Lieben, L.; Mathieu, C.; Demay, M. Vitamin D and human health: Lessons from vitamin D receptor null mice. Endocr. Rev. 2008, 29, 726-776. [CrossRef]

80. Bird, A.P. DNA methylation and the frequency of CpG in animal DNA. Nucleic Acids Res. 1980, 8, $1499-1504$. [CrossRef]

81. Gruenbaum, Y.; Stein, R.; Cedar, H.; Razin, A. Methylation of CpG sequences in eukaryotic DNA. FEBS Lett. 1981, 124, 67-71. [CrossRef]

82. Wang, Y.; Leung, F.C.C. An evaluation of new criteria for $\mathrm{CpG}$ islands in the human genome as gene markers. Bioinformatics 2004, 20, 1170-1177. [CrossRef]

83. Deaton, A.M.; Bird, A. CpG islands and the regulation of transcription. Genes Dev. 2011, 25, 1010-1022. [CrossRef]

84. Feinberg, A.P.; Cui, H.; Ohlsson, R. DNA methylation and genomic imprinting: Insights from cancer into epigenetic mechanisms. Semin. Cancer Biol. 2002, 12, 389-398. [CrossRef]

85. Jones, P.A.; Baylin, S.B. The Epigenomics of Cancer. Cell 2007, 128, 683-692. [CrossRef]

86. Fetahu, I.S.; Höbaus, J.; Kállay, E. Vitamin D and the epigenome. Front. Physiol. 2014, 5, 164. [CrossRef]

87. Rosenbloom, K.R.; Armstrong, J.; Barber, G.P.; Casper, J.; Clawson, H.; Diekhans, M.; Dreszer, T.R.; Fujita, P.A.; Guruvadoo, L.; Haeussler, M.; et al. The UCSC Genome Browser database: 2015 update. Nucleic Acids Res. 2015, 43, D670-D681. [CrossRef]

88. Flicek, P.; Amode, M.R.; Barrell, D.; Beal, K.; Billis, K.; Brent, S.; Carvalho-Silva, D.; Clapham, P.; Coates, G.; Fitzgerald, S.; et al. Ensembl 2014. Nucleic Acids Res. 2014, 42, D749-D755. [CrossRef]

89. Takeyama, K.I.; Kato, S. The vitamin D3 lalpha-hydroxylase gene and its regulation by active vitamin D3. Biosci. Biotechnol. Biochem. 2011, 75, 208-213. [CrossRef]

90. Halsall, J.A.; Osborne, J.E.; Hutchinson, P.E.; Pringle, J.H. In silico analysis of the $5^{\prime}$ region of the Vitamin D receptor gene: Functional implications of evolutionary conservation. J. Steroid Biochem. Mol. Biol. 2007, 103, 352-356. [CrossRef]

91. Nair-Shalliker, V.; Dhillon, V.; Clements, M.; Armstrong, B.K.; Fenech, M. The association between personal sun exposure, serum vitamin $\mathrm{D}$ and global methylation in human lymphocytes in a population of healthy adults in South Australia. Mutat. Res. - Fundam. Mol. Mech. Mutagen. 2014, 765, 6-10. [CrossRef]

92. Chavez Valencia, R.A.; Martino, D.J.; Saffery, R.; Ellis, J.A. In vitro exposure of human blood mononuclear cells to active vitamin D does not induce substantial change to DNA methylation on a genome-scale. J. Steroid Biochem. Mol. Biol. 2014, 141, 144-149. [CrossRef] 
93. Falsetti, P.; Acciai, C.; Palilla, R.; Bosi, M.; Carpinteri, F.; Zingarelli, A.; Pedace, C.; Lenzi, L. Oropharyngeal Dysphagia after Stroke: Incidence, Diagnosis, and Clinical Predictors in Patients Admitted to a Neurorehabilitation Unit. J. Stroke Cerebrovasc. Dis. 2009, 18, 329-335. [CrossRef]

94. Nguyen, T.T.T.; Tsujiguchi, H.; Kambayashi, Y.; Hara, A.; Miyagi, S.; Yamada, Y.; Nakamura, H.; Shimizu, Y.; Hori, D.; Suzuki, F.; et al. Relationship between Vitamin Intake and Depressive Symptoms in Elderly Japanese Individuals: Differences with Gender and Body Mass Index. Nutrients 2017, 9, 1319. [CrossRef]

95. Martino, G.; Catalano, A.; Bellone, F.; Langher, V.; Lasco, C.; Penna, A.; Nicocia, G.; Morabito, N. Quality of life in postmenopausal women: Which role for vitamin D? Mediterr. J. Clin. Psychol. 2018, 6. [CrossRef]

96. Eid, A.; Khoja, S.; AlGhamdi, S.; Alsufiani, H.; Alzeben, F.; Alhejaili, N.; Tayeb, H.O.; Tarazi, F.I. Vitamin D supplementation ameliorates severity of generalized anxiety disorder (GAD). Metab. Brain Dis. 2019, 34, 1781-1786. [CrossRef]

(C) 2020 by the authors. Licensee MDPI, Basel, Switzerland. This article is an open access article distributed under the terms and conditions of the Creative Commons Attribution (CC BY) license (http://creativecommons.org/licenses/by/4.0/). 